\title{
KOMPENSASI DAN IKLIM ORGANISASI SEKOLAH TERHADAP KEPUASAN KERJA GURU SEKOLAH DASAR
}

\author{
Oleh: \\ Rani Oktapiani, Diding Nurdin, Abubakar \\ Universitas Pendidikan Indonesia \\ (email: Ratnikindustries01@gmail.com)
}

\begin{abstract}
ABSTRAK:
Penelitian ini bertujuan untuk mengetahui bagaimana kondisi deskriptif kepuasan kerja guru, kompensasi dan iklim organisasi, serta seberapa besar pengaruh kompensasi dan iklim organisasi terhadap kepuasan kerja guru Sekolah Dasar di Kota Cimahi. Metode penelitian yang dilakukan menggunakan metode deskriptif dengan pendekatan kuantitatif yang didukung dengan studi dokumentasi serta angket sebagai alat pengumpulan data. Lokasi penelitian ini di Sekolah Dasar Kota Cimahi dengan sampel guru dijadikan sebagai responden penelitian. Penelitian ini dilakukan terhadap 146 guru di Sekolah Dasar Negeri dan Swasta di Kota Cimahi. Hasil Penelitian mengungkapkan bahwa kompensasi dan iklim organisasi berpengaruh secara signifikan terhadap kepuasan kerja guru. Rekomendasi dari penelitian ini yaitu terutama dalam aspek penetapan gaji dan honor yang diterima belum memenuhi kebutuhan hidup dengan layak, pimpinan sekolah perlu meninjau kembali kebijakan honor bagi para guru serta guru diharapkan mampu akrab dalam berdiskusi, selalu bekerja sama dengan semangat, dan selalu berteman baik dengan siapa pun agar proses akademik di sekolah berjalan dengan baik
\end{abstract}

Kata kunci : Iklim Organisasi, Kepuasan Kerja, Kompensasi Kerja.

\section{ABSTRACT:}

This research is driven by compensation, organizational climate and job satisfaction. The focus of this study is how descriptive the teacher's job satisfaction, compensation and organizational climate are, and how much the influence of compensation and the organizational climate on job satisfaction of elementary school teachers in Cimahi City. The research method used descriptive method with quantitative approach supported by documentation and questionnaire as a tool for collecting data. The location of this study was at the Cimahi City Basic School with the sample of the teachers being used as the respondents of the study. This study was conducted on 146 teachers at the Public and Private Primary School in Cimahi City. The recommendation of this study, especially in terms of setting the salary and honor received has not been sufficiently fulfilled with the needs of the school, the school leaders need to review the honorarium for teachers and teachers who are expected to be familiar with discussions, always cooperate with the spirit, and always be good friends with anyone to keep the academic process in school running smoothly

Keywords: Job Compensation, Job Satisfaction, Organizational Climate.

\section{PENDAHULUAN}

Pendidikan merupakan salah satu faktor yang dapat meningkatkan taraf hidup manusia. Dengan pendidikan manusia memiliki kemampuan, keahlian, sikap dan menjadi lebih dewasa, sehingga mampu meningkatkan kesejahteraan keluarga, masyarakat dan bangsa. Undang-Undang Sisdiknas No. 20 Tahun 2003 pasal 1 menyatakan bahwa pendidikan adalah usaha sadar dan terencana untuk mewujudkan suasana belajar dan proses pembelajaran agar peserta didik secara aktif mengembangkan potensi dirinya untuk memiliki kekuatan spiritual keagamaan, pengendalian diri, kepribadian, kecerdasan, akhlak mulia, perlu ketrampilan yang diperlukan dirinya, masyarakat, bangsa dan Negara.
Pembangunan pendidikan bertujuan mengembangkan sumber daya manusia dengan berbagai program yang professional dan berkualitas. Keberadaan pendidikan yang berkualitas akan menentukan kualitas sumber daya manusia terutama untuk generasi muda. Untuk meningkatkan kualitas pada proses pembelajaran di kelas dibutuhkan dukungan oleh tenaga yang kompeten, kepemimpinan, iklim sekolah baik fisik maupun social. Keberhasilan pendidikan di sekolah tergantung sumber daya yang ada di sekolah seperti kepala sekolah, guru, siswa, pegawai tata usaha sera sarana dan prasarana yang memadai.

Kota cimahi merupakan kota yang terletak di Provinsi Jawa Barat yang pertumbuhan nya 
cukup pesat. Pemerintah kota Cimahi selalu berusaha untuk meningkatkan kualitas penduduknya melalui peningkatan pendidikan formal. Walaupun demikian dalam proses belajar mengajar, tentunya masih banyak kekurangankekurangan yang masih perlu untuk ditingkatkan. Untuk mewujudkan suasana belajar dan proses pembelajaran yang baik dan benar, maka diperlukan manajemen pendidikan. Engkoswara dan Aan (2012: 93) mengemukakan bahwa fungsi manajemen yang sesuai dengan profil kinerja pendidikan secara umum adalah melaksanakan fungsi planning, organizing, staffing, coordinating, leading (facilitating, motivating, innovating), reporting, controlling. Fungsi perencanaan, pengorganisasian, penyusunan staf, pelaksanaan kegiatan dan pengawasan merupakan esensial pada setiap organisasi tidak terkecuali organisasi pendidikan.

Mengelola lembaga pendidikan pada hakikatnya harus melalui sumber daya manusia agar segala sesuatu yang diharapkan dapat terlaksana. Dengan demikian walaupun manajemen itu harus memperhatikan tersedianya bahan, modal, teknologi, dan lain-lain, faktor sumber daya manusia sangatlah menentukan terhadap keberhasilan manajemen mulai dari perencanaan sampai dengan pengawasan kiranya faktor manusia tak dapat tidak harus dipertimbangkan (Sukanto Reksohadiprodjo, 2000:16) dan merupakan bagian dari sumber daya manusia.

Fakta empiris menunjukan jumlah guru meningkat tetapi lembaga kurang optimal dalam memanfaatkannya. Salah satu keterbatasan lembaga untuk memanfaatkan secara optimal yaitu anggaran. Pemerintah secara optimal belum memberikan perhatian terhadap guru terutama kompenasi yang layak bagi guru honorer. Guru honorer atau guru tidak tetap adalah guru yang diangkat atau dipekerjakan di sekolah GTT (guru tidak tetap) ini adalah guru yang diangkat atau dipekerjaan dalam suatu sekolah untuk jangka waktu tertentu guna melaksanakan tugas dalam pengajaran pendidikan yang bersifat teknis professional dan administrasi sesuai dengan kebutuhan dan kemampuan dalam kerangka sistem kepegawaian dibawah arahan dinas pendidikan. GTT ini tidak berkedudukan sebagai PNS (pegawai negeri sipil) dan dapat diberhentikan oleh pihak sekolah dalam waktu tertentu.

Sebagian besar guru honorer atau guru tidak tetap belum memperoleh kompensasi yang cukup untuk standar hidup layak yaitu di bawah upah minimum regional. Banyak guru-guru yang akhirnya memilih pekerjaan yang lain karena rendahnya kompensasi yang diterima . sebagian besar guru justru memiliki tenaga potensial yang memiliki kemampuan dalam mendidik dan mengajar. besaran kompensasi terhadap guru mencerminkan dari kurang pekanya pengambil kebijakan terhadap permasalahan pendidikan. Guru bukan alat produksi agar output berkualitas dengan biaya rendah, oleh karena itu kompensasi yang di peroleh guru diharapkan lebih layak dan menjadi prioritas.

Permasalahan kompensasi banyak terjadi di sekolah-sekolah dengan anggaran terbatas akan tetapi belum menjadi prioritas pengambil kebijakan, Padahal guru sangat menentukan kualitas pendidikan saat ini dan masa depan. Kompensasi menjadi salah satu factor penting yang perlu dpertimbangkan dalam mendorong agar guru bekerja lebih produktif sehingga bekerja lebih optimal. Menurut mathis dan Jackson (2006: 118) kompensasi merupakan factor penting yang mempengaruhi bagaiaman dan mengapa orangorang bekerja pada suatu organisasi buka pada organisasi yang lain. Permasalahan kompensasi guru honorer atau guru tidak tetap masih belum terselesaikan.

Salah satu factor lain sebagai suatu masalah dalam organisasi sekolah adalah iklim organisasi. Iklim organisasi yang kondusif harus dikelola secara efektif dan efisien dalam kepuasan guru honorer atau guru tidak tetap. Iklim organisasi sekolah berkaitan dengan kondisi fisik dan social. Keberadaan iklim organisasi juga mendukung guru menentukan sikap terhadap lembaga. Lembaga perlu mengembangkan budaya yang menempatkan guru dalam posisi yang memuaskan, karena sub budaya mengganggap guru PNS menempati kelompok ekslusif. Sehingga sub budaya tersebut perlu di hilangkan agar guru honorer tetap dihargai tanpa membedakan status kepegawaiannya.

Iklim organisasi mengacu terhadap aspek psikologis yang dirasakan guru terhadap lingkungan di sekolah. Iklim organisasi sekolah, dalam hal ini menyangkut penempatan, kepuasan guru dan deskripsi pekerjaan. Merujuk pada kajian penelitian terdahulu, walaupun terdapat beberapa kesamaan variabel yang diteliti, namun demikian penulis menyakini bahwa penelitian yang dilakukan peneliti tidak duplikasi atau melakukan plagiasi. Originalitas penelitian yang dilakukan peneliti terlihat pada variabel yang diteliti, alat analisis dan lokasi penelitian yang berbeda. Dalam beberapa penelitian terdahulu yang di muat Jurnal "pengaruh iklim organisasi dan kepuasan kerja terhadap kinerja guru" yang ditulis oleh Herman jalani AR, bahwa iklim organisasi secara langsung berpengaruh signifikan terhadap kinerja guru. 
Besarnya pengaruh iklim organisasi secara langsung adalah 55\%.

Dengan demikian berdasarkan uraian diatas dan hasil penelitian terdahulu tadi, dapat disimpulkan ada yang menarik tentang iklim organisasi, kepuasan kerja dan kinerja guru. Adapun fenomena yang terjadi dilapangan hasil pengamatan penulis menujukan bahwa sekolah belum bisa memberikan kompensasi yang layak terhadap guru honorer atau guru tidak tetap. Salah satu kompensasi yang diberikan pemerintah terhadap guru yaitu sertifikasi.

Berdasarkan dari data Dinas Pendidikan Kota Cimahi tahun 2017 bahwa sertifikasi guru sekolah dasar kota Cimahi yang sudah tersertifikasi berjumlah 1.060 guru yaitu $48 \%$, sedangkan yang belum sertifikasi berjumlah 1157 guru yaitu 52\% bisa dilihat dari berikut ini.

Tabel 1.1

\begin{tabular}{ccc}
\multicolumn{3}{c}{ Sertifikasi Guru Sekolah Dasar Kota Cimahi } \\
\hline Sertifikasi Guru & $\begin{array}{c}\text { Jumlah } \\
\text { guru }\end{array}$ & Persentase \\
Sudah Sertifikasi & 1.060 & $48 \%$ \\
Belum Sertifikasi & 1.157 & $52 \%$ \\
Jumlah & 2.217 & $100 \%$ \\
\hline
\end{tabular}

Sumber : Dinas Pendidikan Kota Cimahi, 2017.

Beberapa alasan peneliti mengambil judul ini, Pertama, kompensasi yang diterima guru atas pelaksanaan tugas dalam pendidikan belum sebanding dengan pengakuan dan tuntutan terhadap tugas dan jabatan guru baik dari pemerintah maupun dari masyarakat yaitu bagaimmana seorang guru dapat mencetak sumber daya manusia yang handal, cerdas, bermoral, mandiri dan bertanggung jawab. Masalah kompensasi dalam hal ini menyangkut gaji dan tunjangan yang di terima guru, karena pada akhirakhir ini menjadi factor ketidakpuasan guru terhadap kebijakan pemerintah karena apa yang diterima guru belum dapat memenuhi kebutuhan hidupnya. Penelitian ini berfokus tentang kompensasi yang diterima guru sekolah dasar Cimahi baik dalam bentuk uang atau non uang terhadap Kepuasan kerja, kompensasi dan iklim organisasi sekolah.

Kedua, iklim organisasi sekolah tidak lepas dari lingkungan kerja dalam organisasi, Ketika guru merasakan kondisi lingkungan

Pada dasarnya kepuasan kerja merupakan sikap individu yang berbeda-beda, sekalipun berada dalam tipe pekerjaan yang sama hal ini tergantung tingkat kebutuhannya dan sistem yang berlaku pada dirinya. Malayu S.P Hasibuan pekerjaan yang nyaman, baik, terbuka, dan ketika guru merasakan tingkat kebutuhan terpenuhi secara adil dan layak, maka kinerja guru akan lebih baik. Tetapi dengan iklim organisasi yang berjalan kurang baik, lokasi dan lingkungan fisik sekolah, sarana/prasarana yang kurang memadai untuk proses pembelajaran yang baik. Kondisi seperti ini memicu ketidak puasan guru dalam melaksanakan tugasnya.

Ketiga, pemilihan subjek dan objek penelitian yaitu guru-guru SD Negeri dan Swasta di kota Cimahi yang merupakan satu kawasan pertumbuhan Kota Bandung di sebelah barat. Jumlah penduduknya saat ini adalah sekitar 483.000 jiwa, meningkat dari 290.000 pada tahun 1990 dengan pertumbuhan rata-rata $2,12 \%$ per tahun. Dengan luas wilayah mencapai $48,42 \mathrm{~km}$, cimahi memiliki 3 kecamatan yaitu, kecamatan cimahi tengah, cimahi selatan dan cimahi utara. Kota Cimahi berbatasan langsung dengan Kota Bandung, Kabupaten Bandung dan Kabupaten Bandung Barat. Kota Cimahi memiliki kemudahan akses dan dapat di tempuh baik melalui jalan tol atau jalur kereta api. Cimahi telah lama dikenal sebagai kota industri, terutama industri tekstil dan manufaktur. Dipandang dari sisi lingkungan social ekonomi cimahi merupakan wilayah iindustri dan perdagangan yang berdampak pada tingkat partisipasi masyarakat pada program yang dilaksanakan oleh pemerintah atau masyarakat. Ketika status dan tingkat kesejahteraan serta tingkat kemampuan ekonomi masyarakat cukup baik maka partisipasi masyarakat akan baik. Dan sebaliknnya bila tingkat kemampuan ekonomi masyarakat rendah maka partisipasi masyarakat juga rendah.

Penyelenggaraan pendidikan dasar di Kota Cimahi berdasarkan data dinas pendidikan kota cimahi berjumlah 125 SD negeri dan swasta. Data 2017 yang dikeluarkan dinas pendidikan kota cimahi memberikan informasi bahwa jumlah guru yang mengajar pada 125 SD sebanyak 2217, terdiri dari 497 guru honorer dan 1349 guru PNS . Penelitian ini membahas mengenai kompensasi dan iklim organisasi sekolah tehadap kepuasan kerja guru yang berdampak pada kinerja guru di sekolah serta berimplikasi pada pengelolaan dan pemelihiaraan guru yang memiliki kompetensi professional, pedagogig, kepribadian serta sikap sosial yang patut diteladani.

\section{A. Kepuasan Kerja}

(2008:202), menyatakan bahwa kepuasan kerja adalah sikap emosional yang menyenangkan dan mencintai pekerjaannya. Sikap ini dicerminan oleh moral kerja, kedisiplinan dan prestasi kerja. Husain Umar ( 2008: 213 ), menyatakan bahwa 
:'Kepuasan kerja adalah perasaan dan penilaian seorang atas pekerjaannya, khususnya mengenai kondisi kerjanya, dalam hubungannya dengan apakah pekerjaannya mampu memenuhi harapan, kebutuhan, dan keinginannya". Menurut pendapat Stephen Robbins (2003:91) istilah kepuasan kerja merujuk kepada sikap umum seorang individu terhadap pekerjaan yang dilakukannya. Seseorang dengan tingkat kepuasan kerja tingggi menunjukan sikap yang positif terhadap kerja itu; seseorang yang tidak puas dengan pekerjaannya menunjukan sikap yang negatif terhadap pekerjaan itu. karena pada umumnya apabila orang berbicara mengenai sikap karyawan, lebih sering mereka memaksudkan kepuasan kerja. Robbins menyatakan kepuasan itu terjadi apabila kebutuhan-kebutuhan individu sudah terpenuhi dan terkait dengan derajat kesukaan dan ketidaksukaan dikaitkan dengan pegawai, merupakan sikap umum yang dimiliki oleh pegawai yang erat kaitannya dengan imbalanimbalan yang mereka yakini akan mereka terima setelah melakukan pengorbanan.

Menurut Nelson and Quick (2005: 83) mendefinisikan kepuasan kerja sebagai berikut: Job satisfaction is a pleasurable or positive emotional state resulting from the appraisal of one's job or job experiences. Berdasarkan pendapat di atas sesuatu yang berhubungan dengan pekerjaan meliputi aspek-aspek penggajian, kesempatan berkarir, struktur organisasi perusahaan, mutu. Sedangkan yang berhubungan dengan dirinya antara lain umur, kondisi kesehatan, pendidikan dan kompetensi.

Sedangkan menurut Hani Handoko (2007:193), menyatakan bahwa : 'Kepuasan kerja adalah keadaan emosional yang menyenangkan atau tidak menyenangkan dimana para karyawan memanadang pekerjaan mereka". Setiap individu yang masuk dalam lingkungan kerja membawa kebutuhan yang ingin dipenuhinya. Kebutuhan itu menjadi pendorong baginya untuk berusaha memperoleh tujuannya. Apabila kebutuhan yang diharapkannya dari pekerjaan tersebut terpenuhi, maka ia akan merasa puas, dan jika kebutuhan tersebut tidak terpenuhi maka ia akan mengalami ketidakpuasan. Kepuasan mempunyai arti penting bagi karyawan maupun perusahaan karena akan membawa dampak positif dalam lingkungan pekerjaan.

\section{B. Kompensasi}

Kompensasi yang diberikan dapat dibedakan dalam bentuk financial dan non financial. Kompensasi financial terdiri dari kompensasi langsung dan tidak langsung. Kompensasi langsung merupakan pembayaran karyawan dalam bentuk gaji, upah, bonus atau komisi. Sedangkan kompensasi tidak langsung, atau benefit, terdiri dari semua pembayaran yang tidak tercakup dalam kompensasi financial langsung yang meliputi liburan, berbagai macam asuransi, uang pensiun, jasa seperti perawatan anak atau kepedulian keagamaan dan sebagainya. Adapun kompensasi non financial berupa penghargaan seperti pujian, menghargai diri sendiri, dan pengakuan yang dapat mempengaruhi motivasi kerja karyawan, produktivitas, dan kepuasan. Rivai (2004:357) mengemukakan bahwa: "Kompensasi merupakan sesuatu yang diterima karyawan sebagai pengganti kontribusi jasa mereka pada perusahaan"

\section{Iklim Organisasi Sekolah}

Definisi mengenai iklim organisasi dikemukakan oleh beberapa ahli. Para ahli Barat mengartikan iklim sebagai unsur fisik, dimana iklim sebagai suatu atribusi dari organisasi atau sebagai suatu atribusi daripada persepsi individu sendiri. Menurut Lussier (2005:486) mengatakan bahwa iklim organisasi adalah persepsi pegawai mengenai kualitas lingkungan internal organisasi yang secara relatif dirasakan oleh anggota organisasi yang kemudian akan mempengaruhi perilaku mereka berikutnya. Kemudian dikemukakan oleh Simamora (2004:81) bahwa iklim organisasi adalah lingkungan internal atau psikologi organisasi. iklim organisasi mempengaruhi praktik dan kebijakan SDM yang diterima oleh anggota organisasi. perlu diketahui bahwa setiap organisasi akan memiliki iklim organisasi yang berbeda. Keaneka ragaman pekerjaan yang dirancang di dalam organisasi, atau sifat individu yang ada akan menggambarkan perbedaan tersebut. Dengan memperhatikan pernyataan dan definisi tentang iklim organisasi maka dapat disimpulkan bahwa iklim organisasi merupakan hal yang sangat penting bagi keberhasilan suatu organisasi. Iklim suatu organisasi akan sangat berbeda dengan iklim organisasi lainnya, karena hal tersebut berkaitan dengan kondisi lingkungan kerja masing-masing organisasi. 1

Iklim sekolah, pada dasarnya dapat dikemukakan sebagai iklim organisasi yang terjadi di sekolah. Iklim organisasi sekolah merupakan hasil dari media interaksi dalam organisasi sekolah. Iklim organisasi apabila dikaitkan dengan guruguru dalam bekerja sama melaksanakan kondisi lingkungan organisasi sekolah dimana guru-guru melaksanakan tugasnya. Karena atmosfer sebuah 
sekolah menimbulkan dampak besar terhadap prilaku organisasi, dank arena para penyelenggara sekolah bisa menimbulkan pengaruh yang signifikan dan potensial bagi perkembangan kepribadian sekolah, maka penting sekali melukiskan san menganalisis iklim sekolah. Hoy dan Miskel (2014:311) menambahkan bahwa lingkungan kerja yang kurang mendukung seperti lingkungan fisik pekerjaan dan hubungan kurang serasi antara seseorang guru dengan guru lainnya ikut menyebabkan kinerja menjadi buruk. Hoy dan Miskel (2014:198), mengemukakan bahwa :

Organization climate is a relatively enduring quality of scool environment that experience by teachers affect their behavior, and is besed on their collective perpection of behavior in school. A climate emerges through the interaction of members and exchange of sentiment omong them. The climate of a school is its "personality"

Pernyataan diatas apabila diterjemahkan berarti: Iklim organisasi adalah kualitas lingkungan sekolah yang berlangsung secara relatif yang dialami oleh guru yang memengaruhi sikap-sikapnya dan itu berdasarkan kepada kepentingan secara bersama tentang "sikap" di sekolah. Suatu iklim organisasi timbul melalui interaksi dari anggota dan pertukaran perasaan diantara mereka dan iklim organisasi sekolah adalah kepribadiannya. Dengan demikian, iklim organisasi sekolah dapat didefinisikan sebagai suasana lingkungan sekolah, baik lingkungan fisik maupun lingkungan sosial pekerjaan yang dapat dirasakan oleh orang-orang yang terlibat didalam proses pembelajaran, langsung atau tidak langsung yang tercipta akibat kondisi kultural organisasi sekolah tersebut serta memberikan atmosfer pada sekolah yang menimbulkan dampak terhadap terhadap prilaku organisasi, secara signifikan dan potensial bagi perkembangan kepribadian sekolah.

\section{METODE PENELITIAN}

Penelitian ini menggunakan pendekatan kuantitatif untuk mengetahui seberapa besar pengaruh kompensasi dan iklim organisasi terhadap kepuasan kerja guru di Sekolah Dasar Kota Cimahi. Adapun metode penelitian dalam penelitian ini menggunakan metode desktiptif untuk membuat deskripsi, gambaran mengenai fakta-fakta, sifat serta hubungan yang terjadi antara variabel dependen dan independen. Data penelitian diambil menggunakan teknik angket pada guru SD Kota Cimahi berjumlah 146 orang responden.

Gambar 2. Desain Penelitian $\mathrm{X}_{1}, \mathrm{X}_{2}$, dan $\mathrm{Y}$
Teknik analisis data yang digunakan pada penelitian ini yaitu analisis korelasi sederhana,

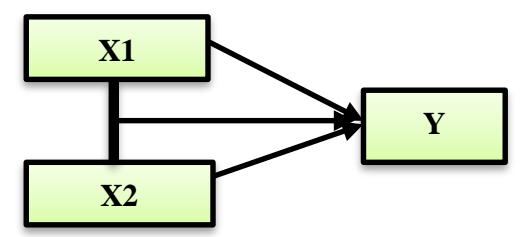

analisis regresi sederhana, analisis korelasi ganda, analisis regresi ganda, koefisien determinasi, uji t, dan uji F. Pengolahan analisis data pada penelitian ini menggunakan bantuan SPSS Ver.17 untuk membantu penulis dalam menghitung data.

\section{HASIL PENELITIAN}

\section{Hasil Analisis Data Deskriptif}

Berikut ini hasil analisis data deskriptif pada setiap variabel penelitan: 
a. Kompensasi

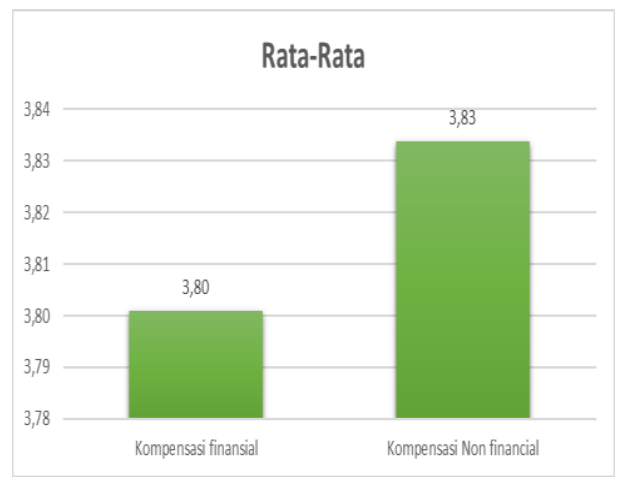

Gambar 3. Grafik Rata-rata Kompensasi

b. Iklim Organisasi Sekolah

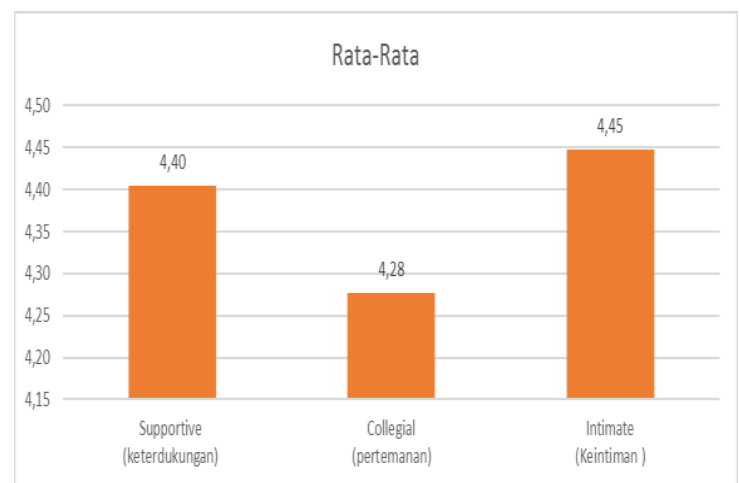

Gambar 4. Grafik Rata-rata Iklim Organisasi c. Kepuasan Siswa

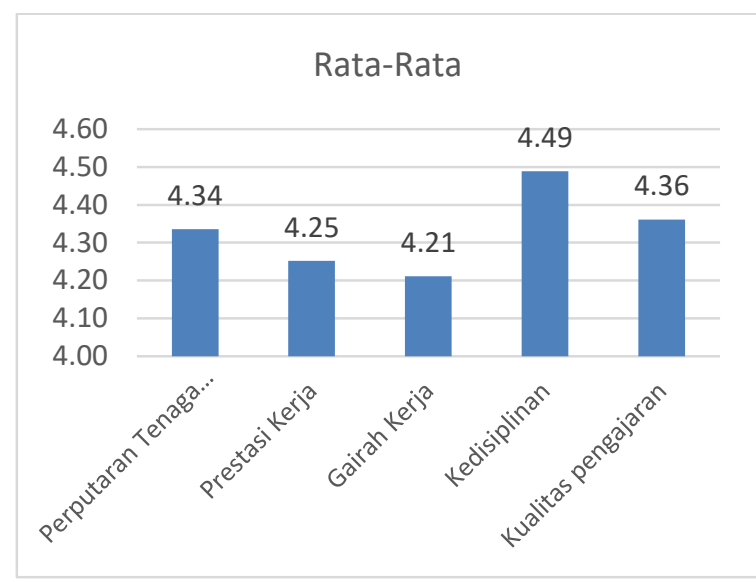

Gambar 5. Grafik Rata-rata Kepuasan Siswa

\section{Hasil Pengujian Hipotesis}

Berikut ini rangkuman hasil analisis data pada variabel Kompensasi $\left(\mathrm{X}_{1}\right)$, Iklim Organisasi $\left(\mathrm{X}_{2}\right)$, dan kepuasan kerja (Y):

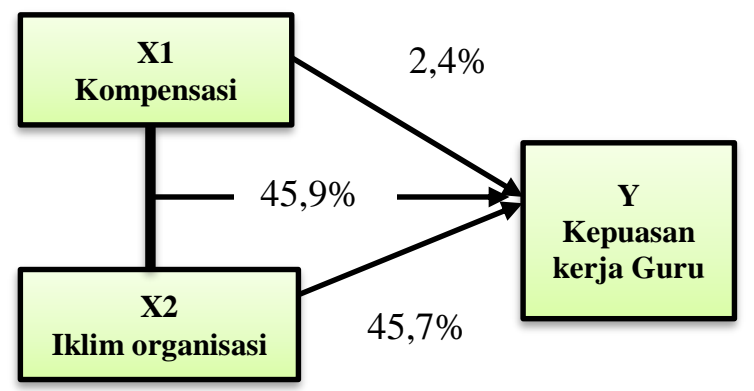

Gambar 6. Rangkuman Analisis Data

\section{PEMBAHASAN}

\section{A. Deskripsi Kompensasi}

Setelah dilakukan penelitian di lapangan dan didapatkan hasil perhitungan kompensasi secara keseluruhan mempunyai skor gambaran rata-rata sebesar 3,82 yang artinya faktor kompensasi yang ada di SD Kota Cimahi berkriteria Tinggi. Berdasarkan hasil perhitungan menggunakan Weight Means Scored (WMS) yang diperoleh skor tertinggi yaitu kategori kompensasi non finansial dengan skor 3,83, sedangkan skor terendah yaitu pada kategori kompensasi finansial dengan skor 3,80 .

Dalam rangka peningkatan kualitas kinerja guru, kompensasi merupakan hal penting yang mempengaruhi tingkat kepuasan seorang guru. Kompensasi merupakan setiap bentuk penggajian dan ganjaran yang mengalir kepada pegawai atau timbul dari kepegawaian mereka (Garry Dessler, 2003: 349). Setiap orang yang bekerja pasti menghasil produk baik barang maupun jasa, dari produk tersebut para pegawai diberikan pengupahan berupa kompensasi yang setimpal atas pekerjaan mereka di organisasi tersebut. Berdasarkan hasil temuan, kompensasi penting bagi para guru sebagai individu yang memberikan kewajibannya sebagai tenaga pendidik. Besarnya kompensasi mencerminkan ukuran nilai karya dan tanggung jawab mereka sebagai pencetak generasi masa depan sebagai generasi yang terdidik.

\section{B. Deskripsi Iklim Organisasi}

Setelah dilakukan penelitian di lapangan dan didapatkan hasil perhitungan iklim organisasi secara keseluruhan mempunyai skor gambaran rata-rata sebesar 4,38 yang artinya faktor iklim organisasi yang ada di SD Kota Cimahi berkriteria Sangat Tinggi. Berdasarkan hasil perhitungan menggunakan Weight Means Scored (WMS) yang diperoleh skor tertinggi yaitu kategori keintiman dengan skor 4,45 , sedangkan skor terendah yaitu pada kategori pertemanan dengan skor 4,28.

Iklim merupakan suatu keadaan yang menunjukkan suatu kehidupan yang saling berinteraksi, sehingga menimbulkan rasa senang atau tidak senang terhadap bidang pekerjaannya. 
Arti interaksi yang dimaksud adalah adanya hubungan antara atasan dan bawahan serta bawahan dengan bawahan lainnya. Hal ini terjadi dalam proses interaksi adalah adanya suatu komunikasi yang dijadikan sebagai media untuk menyampaikan pesan sehingga ada hubungan atau respon dari yang menerima informasi.

Keith Davis dan John W. Newstrom (1994: 24) dalam penelitiannya menyebutkan beberapa faktor yang dapat mengukur iklim organisasi: Kualitas kepemimpinan, kadar kepercayaan, komunikasi keatas dan ke bawah, perasaan melakukan pekerjaan yang bermanfaat, tanggung jawab, imbalan yang adil, tekanan pekerjaan yang nalar, kesempatan, pengendalian, struktur, dan birokrasi yang nalar dan keterlibatan pegawai. Selanjutnya Steers (2005:32) mengemukakan bahwa ada empat faktor yang menentukan iklim suatu organisasi. Keempat faktor tersebut ialah: struktur organisasi, teknologi, lingkungan luar dan kebijakan suatu proses manajemen.

Iklim sekolah, pada dasarnya dapat dikemukakan sebagai iklim organisasi yang terjadi di sekolah. Iklim organisasi di sekolah merupakan suatu bentuk interaksi satu sama lainnya yang secara bersama sama terlibat dalam suatu lingkungan sekolah dan menciptakan kondisi dan suasana proses pembelajaran. Hoy dan Miskel (2001: 431) iklim organisasi adalah kualitas lingkungan sekolah yang berlangsung secara relatif yang dialami oleh guru mempengaruhi sikapsikapnya dan itu berdasarkan kepada kepentingan secara bersama tentang sikap di sekolah. Suatu iklim akan timbul melalui interaksi dari anggota dan pertukaran perasaan diantara mereka. Iklim organisasi yang paling baik adalah open climate artinya sekolah dengan iklim terbuka berarti ada kerja sama dan saling menghormati antara guru dan karyawan, serta elemen sekolah lainnya.

Iklim organisasi di sekolah akan memberi pengaruh pada perilaku guru dalam melaksanakan tugasnya di sekolah. Pentingnya memperhatikan iklim yang ada pada organisasi sekolah merupakan suatu gambaran bahwa pencapaian tujuan organisasi sekolah juga akan banyak ditentukan oleh bagaimana tata kelola lingkungan sekolah itu sendiri sebagai pembentuk kepribadian para warganya. Iklim organisasi sekolah membangun situasi yang kondusif bagi guru dan staf untuk melaksanakan tugas masing-masing dalam menunjang kinerjanya agar suasana akademik dan proses pembelajaran berjalan optimal.

\section{Deskripsi Kepuasan Kerja}

Setelah dilakukan penelitian di lapangan dan didapatkan hasil perhitungan kepuasan kerja guru secara keseluruhan mempunyai skor gambaran rata-rata sebesar 4,33 yang artinya kepuasan kerja guru yang ada di SD Kota Cimahi berkriteria sangat Tinggi. Berdasarkan hasil perhitungan menggunakan Weight Means Scored (WMS) yang diperoleh skor tertinggi yaitu kategori kedisiplinan guru terhadap pekerjaannya, sedangkan skor terendah yaitu pada kategori gairah kerja.

Merujuk pada hasil penelitian tersebut, kepuasan kerja guru merupakan hal yang penting dan harus menjadi perhatian sekolah dalam menyelenggarakan pendidikan di sekolah. Kepuasan kerja di dalam sekolah bersifat dinamis yang artinya, perasaan puas dapat berubah-ubah sesuai dengan kondisi yang dialami individu. Kepuasan kerja berhubungan erat dengan sikap guru terhadap pekerjaannya sendiri, karena semakin tinggi tingkat kepuasan kerja seseorang akan tercermin dari sikap kearah yang lebih baik.

Kepuasan kerja merupakan impian dan harapan setiap guru, akan tetapi banyak faktor yang menyebabkan puas atau tidaknya seorang guru dalam mengajar. Menurut Halawa (2002: 12) menyebutkan beberapa faktor yang mempengaruhi kepuasan kerja, yaitu lingkungan kerja, disiplin kerja, gaji, hubungan guru dengan orang lain di sekolah, motivasi mengajar, kepemimpinan kepala sekolah dan pengetahuan dan komunikasi.

Apabila guru merasa tidak puas, maka akan muncul perilaku-perilaku yang berpengaruh terhadap kinerja mengajar duru. Diantaranya yaitu guru merasa bahwa dirinya sudah tidak efektif dalam membantu siswa belajar dan tidak ada motivasi dalam memenuhi tanggung jawab lain di sekolah mereka. Sikap guru terhadap pekerjaan dapat dilihat dalam bentuk persepsi dan motivasi kerja yang ditampilkan. Guru yang memiliki sikap positif yang baik terhadap pekerjaannya, akan selalu berpikir secara matang dan bersikap secara profesional yang baik. Sikap positif maupun negatif guru tergantung bagaimana suasana yang bersangkutan terhadap lingkungan sekitarnya.

\section{Pengaruh Kompensasi terhadap Kepuasan Guru guru SD yang ada di Kota Cimahi.}

Berdasarkan hasil penelitian diperoleh hubungan antara variabel Kompensasi (X1) dengan Kepuasan (Y) dengan nilai $\alpha$ sebesar 0,059 atau > 0,05 menunjukkan hubungan tidak signifikan pada kedua variabel tersebut. Hasil perhitungan korelasi Product Moment (Pearson Correlation) dengan nilai sebesar 0,154 menunjukkan hubungan yang lemah atau dapat diabaikan. Dapat diketahui besarnya koefisien determinasi variabel Kompensasi $\left(\mathrm{X}_{1}\right)$ terhadap variabel Kepuasan $(\mathrm{Y})$ 
adalah sebesar 0,024 atau 2,4\%. Artinya Kepuasan dipengaruhi oleh variabel Kompensasi sebesar $2,4 \%$, dan selebihnya dengan $97,6 \%$ dipengaruhi faktor lain.

Mathis dan Jackson (2006: 118) mengungkapkan bahwa kompensasi merupakan faktor penting mengapa orang-orang bekerja pada suatu organisasi dan bukan organisasi lain. Kompensasi yang layak akan membuat guru tidak lagi memikirkan hal lain selain mengajar, dengan kata lain bahwa guru tersebut akan fokus terhadap pembelajaran dikelas sebagai tugas utamanya, kompensasi yang layak juga merupakan penghargaan bagi dedikasi seorang guru yang telak melaksanakan tugas mendidik siswa.

Pengaruh Pengaruh iklim terhadap kepuasan kerja guru SD yang ada di Kota Cimahi.

Berdasarkan hasil penelitian hubungan antara variabel Iklim (X2) dengan Kepuasan (Y) dengan nilai $\alpha$ sebesar 0,000 atau $<0,05$ menunjukkan hubungan signifikan pada kedua variabel tersebut. Hasil perhitungan korelasi Product Moment (Pearson Correlation) dengan nilai sebesar 0,667 menunjukkan hubungan yang kuat. Dapat diketahui besarnya koefisien determinasi variabel Iklim $\left(\mathrm{X}_{2}\right)$ terhadap variabel Kepuasan (Y) adalah sebesar 0,457 atau $45,7 \%$. Artinya Kepuasan dipengaruhi oleh variabel iklim sebesar $45,7 \%$, dan selebihnya dengan $54,3 \%$ dipengaruhi faktor lain. Dari hasil penelitian diatas, menunjukkan bahwa variabel iklim organisasi sekolah memberikan pengaruh yang signifikan terhadap kepuasan kerja guru. Artinya semakin baik, iklim organisasi di suatu sekolah makan akan semakin tinggi pula kepuasan kerja guru. Maka dari itu, untuk mengoptimalkan kepuasan kerja guru, iklim organisasi sekolah harus selalu dijaga agar kondusif dan menyenangkan.

Dengan demikian, iklim organisasi merupakan faktor yang penting dalam meningkatkan kepuasan kerja guru. Hasil ini didukung oleh pendapat dari Amirudin (2010: 39) bahwa iklim organisasi dapat mempengaruhi motivasi, prestasi dan kepuasan kerja. Hasil penelitian sesuai dengan Hildebrand dan Walsh (1988) mengemukakan bahwa persepsi sosial dalam lingkungan kerja, lingkungan saling pengaruh satu sama lain. Iklim kerja adalah bagian dari lingkungan sosial yang memiliki pengaruh terhadap kepuasan kerja seseorang.

\section{Pengaruh kompensasi dan iklim organisasi terhadap kepuasan kerja guru SD yang ada di Kota Cimahi.}

Berdasarkan pengolahan data, maka disimpulkan bahwa variabel Kompensasi (X1) dan Iklim $\left(\mathrm{X}_{2}\right)$ berpengaruh signifikan terhadap Kepuasan (Y) menurut persepsi kepala sekolah secara bersama-sama. Dapat diketahui besarnya koefisien determinasi variabel Kompensasi $\left(\mathrm{X}_{1}\right)$ dan Iklim $\left(\mathrm{X}_{2}\right)$ memberikan pengaruh terhadap variabel Kepuasan (Y) adalah sebesar 0,459 atau $45,9 \%$. Artinya Kepuasan dipengaruhi oleh kompensasi dan iklim sebesar 45,9\%, dan selebihnya dengan $54,1 \%$ dipengaruhi faktor lain.

Sondang P. Siagian (2004:126) mengemukakan bahwa Kepuasan kerja pegawai adalah sikap umum seseorang terhadap pekerjaannya, artinya secara umum dapat dirumuskan bahwa seseorang yang memiliki rasa puas terhadap pekerjaannya akan mempunyai sikap yang positif terhadap organisasi dimana ia bekerja. Senada dengan konsep tersebut Pandji Anoraga (1992:82) mengemukakan bahwa: Kepuasan kerja merupakan sikap yang positif yang menyangkut penyesuaian diri yang sehat dari para karyawan terhadap kondisi dan situasi kerja, termasuk di dalamnya masalah upah, kondisi sosial, kondisi fisik, dan kondisi psikologis. Konsep tersebut memberi pengertian bahwa kepuasan kerja merupakan aspek yang sangat positif bagi kemajuan organisasi yang berhubungan dengan masalah upah, keadaan sosial, fisik dan psikologis.

Dengan adanya pembahasan mengenai konsep-konsep kepuasan kerja menunjukkan bahwa kepuasan kerja merupakan faktor yang sangat penting dalam menjamin kehidupan organisasi agar tetap tumbuh dan berkembang sesuai dengan perkembangan zaman dan tuntutan masyarakat. Oleh karena itu, tidak mengherankan apabila perkembangan konsep-konsep kepuasan kerja melahirkan sejumlah teori yang relevan untuk diterapkan dalam kehidupan organisasi, sehingga dapat dijadikan acuan bagi pimpinan organisasi agar pegawai memiliki kepuasan kerja yang relatif stabil bahkan cenderung semakin meningkat. Adapun teori kepuasan kerja menurut Mangkunegara (2004:122) yaitu Teori Keseimbangan, Teori Perbedaan, Teori Pemenuhan Kebutuhan, dan Teori Pandangan Kelompok. 
Berdasarkan hasil penelitian dan analisis data yang telah diuraikan, maka penulis dapat menarik kesimpulan sebagai berikut:

a. Kepuasan kerja guru di Sekolah Dasar Kota Cimahi berada pada kategori sangat tinggi hal ini berarti bahwa kepuasan kerja guru secara Perputaran Kerja, Prestasi Kerja, Gairah Kerja, Kedisiplinan dan Kualitas pengajaran. telah dilakukan dengan baik. Rata-rata yang diperoleh skor tertinggi yaitu kategori kedisiplinan guru terhadap pekerjaannya, sedangkan skor terendah yaitu pada kategori Gairah kerja

b. Kompensasi guru di Sekolah Dasar Kota Cimahi berada pada kategori tinggi. artinya bahwa kompensasi guru secara yaitu kompensasi finansial dan kompensasi non finansial telah dilakukan dengan baik. Ratarata yang diperoleh skor tertinggi yaitu kategori kompensasi non finansial, sedangkan skor terendah yaitu pada kategori kompensasi finansial.

c. Iklim Organisasi di Sekolah Dasar Kota Cimahi berada pada kategori sangat tinggi. Artinya bahwa iklim organisasi dilihat dari indikator Supportive (keterdukungan), Collegial (pertemanan) dan Intimate (Keintiman) telah dilakukan dengan baik. Rata-rata yang diperoleh skor tertinggi yaitu kategori keintiman, sedangkan skor terendah yaitu pada kategori pertemanan.

d. Terdapat pengaruh kompensasi terhadap kepuasan kerja guru SD yang ada di Kota Cimahi dengan signifikansi yang lemah.

e. Terdapat pengaruh antara iklim terhadap kepuasan kerja guru SD yang ada di Kota Cimahi memiliki pengaruh yang signifikan dan berada pada kategori yang kuat.

f. Terdapat pengaruh antara kompensasi dan iklim organisasi terhadap kepuasan kerja guru SD yang ada di Kota Cimahi berada pada kategori tinggi yang berarti keduanya memiliki pengaruh yang signifikan dan positif.

\section{Rekomendasi}

Ada beberapa hal yang perlu dibenahi agar lembaga pendidikan mampu memenuhi kebutuhan dan keinginan siswa untuk mencapai kepuasan dan tujuan pendidikan. Adapun yang perlu dibenahi pada setiap faktor yang ada yaitu:

a. Kepuasan Kerja : Hasil penelitian mengungkapkan bahwa kepuasan kerja guru secara umum sudah sangat tinggi, namun tidak hanya tinggi melainkan harus dijaga dan dipertahankan terutama bagaimana menjaga semangat kerja dalam mengajar, menghargai hasil kerja dan bangga akan keprofesiannya. Rekomendasinya adalah guru harus dilibatkan dan melibatkan diri dalam berbagai penelitian yang dapat meningkatkan kualitas belajar sehingga hasilnya dapat diterapkan dalam pembelajaran sehari-hari.

b. Kompensasi : Dimensi kompensasi yang paling kecil adalah kompensasi secara finansial. Kompensasi secara finansial merupakan suatu pengharapan upah yang diberikan sekolah berupa gaji. Kebutuhan seseorang guru pasti berbeda-beda, maka perlu diperhatikan kembali bagaimana kelayakan hidup dan kebutuhan hidup dengan gaji yang diberikan. Ada sebagian guru yang merasa dari sisi motivasi eksternal terutama berkaitan dengan gaji/bayaran masih dirasa kurang cukup sehingga harus ada penyesuaian gaji/bayaran dengan kebutuhan guru di lapangan.

c. Iklim Organisasi : Ada sebagian guru yang merasa kurang merasa cocok dalam beberapa faktor iklim organisasi. Guru diharapkan mampu akrab dalam berdiskusi, selalu bekerja sama dengan semangat, dan selalu berteman baik dengan siapa pun agar proses akademik di sekolah berjalan dengan baik.

d. Peneliti selanjutnya: Agar lebih fokus peneliti selanjutnya hendaknya melakukan penelitian kompensasi, iklim organisasi dan kepuasan kerja guru secara kualitatif dan banyak dimensi dari kepuasan kerja guru yang harus dikaji lebih mendalam di sekolah atau madrasah, juga mendalami faktor-faktor lain yang mempengaruhi kepuasan kerja guru di sekolah untuk dikaji lebih lanjut serta melakukan penelitian di sekolah dan di komparatif hasilnya dengan penelitian ini. 
A.A.Anwar Prabu Mangkunegara. (2011). Manajemen Sumber Daya Manusia Perusahaan. Bandung :PT.Remaja Rosda Karya.

Aa Suryana. (2012). Guru Profesional. Bandung: PT Refika Aditama

Akdon dan Sahlan Hadi. (2005). Aplikasi Statistika dan Metode Penelitian untuk Administrasi dan Manajemen. Bandung : Dewa Ruchi

Antonio de Pora.(2011). Remunerasi (Kompensasi \& Benefit). Jakarta: Rana Pustaka

Akdon dan Riduwan.( 2008). Rumus dan Data dalam Analisis Statistika. Bandung: Alfabeta

Departemen Pendidikan Nasional, 2003. UndangUndang Nomor 20 Tahun 2003, Tentang Sistem Pendidikan Nasional, Jakarta: Depdiknas.

Dessler, Garry. (2003). Human Resources Management. New Jersey Prentie-Hall

Engkoswara, dan Aan Komariah. (2010). Administrasi Pendidikan. Bandung Alfabeta

Handoko, T Hani, (2001). Manajemen Personalia dan Sumber Daya Manusia. Yogyakarta: BPFE-Yogyakarta

Hasibuan, Malayu S.P. (2006). Manajemen Sumber Daya Manusia. Edisi Revisi. Cetakan Keenam. Jakarta: Bumi Aksara.

Herman jalani. 2014. Pengaruh iklim organisasi dan kepuasan kerja terhadap kinerja guru. Jurnal administrasi pendidikan halaman $157-158$

Husein Umar, 2000, Riset Pemasaran Dan Perilaku Konsumen, Jakarta : PT Gramedia Pustaka

Hoy, Wayne K. \& Miskel, Cecil G. (2014). Education Administration: Theory
Research, and Practice (6th ed., international edition). Singapore: Mc GrawHill Co

Lussier, N Robert. (2005). Human Relations in OrganizationApplications and skill Building.New York: Mc Graw Hill.

Mangkunegara, A.A.P, (2009). Manajemen Sumber Daya Manusia. Bandung: PT. Remaja Rosdakarya

Mathis, dan Jackson. (2002). Manajemen Sumber Daya Manusia Edisi Pertama Cetakan Pertama. Yogyakarta: Salemba Empat

Robbins, Stephen P. (2003) Organizational Behaviour - Concepts, Controversies, and Aplications, Fifth Edition. New Jersey : Prentice-Hall Internasional.

Samuel A. A dan Gombakomba T. (2013) European Scientific JournalDimensions of Teachers' Job Satisfaction in Primary Schools in Gweru District, Zimbabwe: A Factor Analysis.

Veithzal Rivai, 2004, "Manajemen Sumber Daya Manusia Untuk Perusahaan. Cetakan Pertama, Jakarta, PT. Raja GrafindoPersada

Warsidi. (2004). Pengaruh Kompensasi dan Kepuasan Kerja Terhadap Kinerja Guru. Tesis

Wibowo. 2013. Manajemen Kinerja. Jakarta: Rajawali Pers

Yamin, Martinis dan Maisah. 2010. Standarisasi Kinerja Guru. Jakarta: Persada Press.

Yee,W.F. dkk. (2014). The Effect of a Psychological Climate for Creativity on Job Satisfaction and Work Performance. International Journal of Economics and Management, 8:97-116. 